DOI https://doi.org/10.32841/2409-1154.2020.46-1.5

\author{
Baibakova I. M., \\ Candidate of Philological Sciences, Associate Professor, \\ Associate Professor at the Department of Foreign Languages \\ Lviv Polytechnic National University
}

\author{
Hasko O. L., \\ Candidate of Philological Sciences, Associate Professor, \\ Associate Professor at the Department of Foreign Languages \\ Lviv Polytechnic National University
}

\title{
SOCIAL INTERACTION MAXIMIZATION WITHIN DISTANCE LEARNING ESP DISCOURSE CLASSROOM
}

Summary. Successful online learning experience depends on social interaction. The latter is treated as crucial in this respect, hence, its maximization is of primary importance. Practical application of social interaction is regarded in the context of ESP discourse studies within distance learning.

The paper is focused on maximizing social interaction dealing with ESP discourse studies in the framework of the current online tertiary educational process.

ESP discourse mastering is aimed at developing students' competences which will enable them to effectively communicate in their future professional environment. Adequate understanding of authentic materials from Internet sources, journals, instructions, specifications is the result of the previous thorough ESP discourse studies and proper skills based on social interaction. Maximization of the latter for increasing its efficiency and effectiveness is quite obvious since other job-related activities also require high level ESP discourse training and the corresponding social interaction skills and feedback. It refers to: participation in common social, academic and professional settings (meetings, seminars, discussions, talks, debates, etc.); supporting personal professional ideas and point of view with clear argumentation; delivering presentations; conducting lectures; making telephone calls; organising video-conferences, webinars; being members of International cooperation and exchange programmes; writing business correspondence in standard format (e-males, letters, reports, grant proposals, analytical reviews, etc.) for a variety of purposes related to the professional sphere.

Maximizing social interaction efficiency in the virtual classroom directly depends on students' motivation based on their understanding of the ESP discourse practical application as well as on building rapport in terms of mutual respect, trust and group cohesion. Knowledge acquired in the process of ESP discourse training combined with reduced anxiety due to the positive supportive atmosphere leads to beneficial outcomes.

Key words: social interaction, distance learning, ESP discourse, job-related activities, rapport.

The problem being under consideration and its practical application. Successful online learning experience depends on social interaction. The latter is treated as crucial in this respect, hence, its maximization is of primary importance. The practical application of social interaction is regarded in the context of ESP discourse studies within distance learning.
Analysis of the recent publications on the issue. The problem of social interaction not being a new one, is still in the focus of attention $[1 ; 2]$, but it has not been much regarded concerning ESP discourse [3], which as a notion has been studied thoroughly. In this paper these issues are analysed from a different point of view.

The aim of the paper. The paper is focused on maximizing social interaction dealing with ESP discourse studies in the framework of the current online tertiary educational process.

The body of the paper. Karel Kreijns (Faculty of Technical Sciences, Open University of the Netherlands), Paul A. Kirschner and Wim Jochems. (Educational Technology Expertise Center, Open University of the Netherlands) in their article 'Identifying the pitfalls for social interaction in computer-supported collaborative learning environments: a review of the research' dwell on computer-supported collaborative learning environments pitfalls which may block the desired outcome: (1) students' social interaction taken for granted and (2) psychological aspect of social interaction not being taken into consideration. For the social interaction in the virtual learning environment in the course of online education to be efficient it is necessary to develop certain 'sound social spaces characterized by group cohesion, trust, respect and belonging' and establish a special 'sense of community of learning' [4, p. 335].

The research article 'Interaction forms in successful collaborative learning in virtual learning environments' by Essi Vuopala, Pirkko Hyvönen, Sanna Järvelä (University of Oulu, Finland) reads, 'interaction in collaborative situations was more often group-related than task-related. Group-related interaction concentrated mostly on coordination of group work, such as planning and organising group activities' [1, p. 25].

Janette R. Hill (University of Georgia), Liyan Song (Towson University) and Richard E. West (Brigham Young University) in the article 'Social Learning Theory and Web-Based Learning Environments: A Review of Research and Discussion of Implications' argue, 'because cognition is not considered an individual process, learning and knowing are shaped by the kinds of interactions a student has with others, and the context within which these interactions occur' $[2$, p. 89]. The authors also underline the importance of using diverse resources such as text, video and sound making it possible for the learners to explore 'different ways of knowing as well as resources better matching their learning styles, goals, and preferences' [2, p. 91]. 
James Laffey, Guan Yu Lin (University of Missouri-Columbia, United States), Yimei Lin (National Chung Cheng University, Taiwan) in the article 'Assessing Social Ability in Online Learning Environments' point out that 'Education is a social practice and the ability to interact socially is important to social cognitive learning and social learning' [5, p. 163].

According to Patrick Howarth (Teacher, Trainer, Portugal), 'Interaction does not only promote language development but it also fosters the development of social skills (e.g. politeness, respect for others) that people need to operate successfully in any culture' [6]. He also suggests maximising practice time for overcoming students' resistance by using project work and collaborative approach that promotes both realistic language use and interaction. Having different levels of tasks can help in case of mixed abilities.

The ESP discourse teaching has evolved from developments in ESP discourse research. The studies started by analyzing a certain aspect of ESP discourse as it takes place in real life presenting interrelation between spoken ESP discourse and ESP discourse teaching via using transcripts of authentic workplace talk focusing on interpersonal communication namely on language of the meetings, forums etc. and how and why the people use vague language, humor and hedges. In 2012 S. Evans used an approach he applied to teaching ESP emails in English. He found out a close relationship between research and teaching for written ESP discourse where ESP discourse researcher is directly connected with learners. After thorough analysis of 400 ESP emails he came to the conclusion that email communication is in close contact with the spoken communication saying that email users are often connected with specific links that are included into a text and this process is called intertextuality [7].

This analysis was performed in the framework of the ESP discourse research, which is one of the five main areas of research, alongside with Genre analysis, Critical discourse analysis, Organizational rhetoric and Multimodal discourse analysis. For written ESP discourse the analysis of professional texts used in the same context with communicative elements is called ESP Genre analysis which suits ESP discourse teaching in the best way as it aims at providing information about the structure and context of a specific type of text that can be used for teaching. Critical discourse analysis is also tightly connected with the ESP discourse teaching. It usually considers two things: the relationship between a writer and receiver in the text and the aim to keep the work appropriate for the people who interact with discourse rather than falling out of the real world [8].

Multiple data of different types of research show the importance of structure, dialogue and the tutor-learner context that influence the design of ICT based distance ESP learning discourse implementation. The number of social interactions depends on these categories. It can also be closely related to commercial realities of different programmes. Based on these postulates we should consider the research question of how much of social interaction is considered sufficient in designing ICT based distance learning programmes. This research question is divided into the following three areas:

1. What ICT based tools are used by ESP distance learning environment?

2. What strategies do the tutors and learners use to incorporate social interactions?

3. What are the flaws of strategies and tools in practice when emphasising social interactions as a priority? [3]

To answer these questions the multi-case study approach was applied in research to cover different ways of structuring and dia- logue mechanisms and both synchronous and asynchronous delivery mechanisms within the design. The multiple case studies also included a variety of tutor-learner contexts. Therefore the results can be generalised to embrace learner sets. Three main data collection techniques were used within the multi-case study approach registering the data with the web based online portals and discussion forums. Further, the interview technique was used to interview the authors of the programmes, and the survey technique was used to collect data from the learners [3].

As learning is mainly related to a social activity and a person who is doing the work is the person doing the learning, communication and collaboration are critical for learning situations. They are very important to promote such processes as critical thinking and problem solving. Training different situations ESP students possess the opportunity to communicate via discussing and exchanging ideas with others and then develop their personal thinking and in such a way launch coherent collaboration.

In order to help and support students in their communication through a distance learning the computer based Learning Management System (LMS) distributed by the Internet could be used. It provides tools for course production, administration and communication. It could be used both for learning and self-learning as an example of virtual classroom.

By monitoring the system, a tutor can use this information to encourage and give students adequate support and feedback. According to Soong et al [9] there are some critical factors that need to be considered when using a LMS. These include:

1) Human factors - the success of distance learning rests on the main participants.

2) Technical competency - the participants should know the $\mathrm{ABC}$ of computing.

3) Mindset about learning - the way the students and tutors understand learning and self-learning has a substantial impact on how they behave in learning and teaching situations.

4) Level of collaboration - the more you communicate the more you learn. Different kinds of discussion forums, webinars and seminars are of highest priority that are provided via LMS.

5) The level of sensed environment and technical support - technical knowledge and support are very important in distance teaching and learning in order not to create problems in this field [9].

So technology means ease of access and navigation as well as level of interaction. Human factors create security and trust, self discipline and adequate amount of time. Mindset about learning includes feedback, support, monitoring and social processes. Level of collaboration is related to communication, discussion forums, social interaction, designing tasks supporting collaboration and level of sensed environment and technical support deals with such categories as user friendly systems as a technical problem means lack of flexibility and access to technical support and social interaction [9].

A tool, as a LMS, can cover the communicative, collaborative and feedback requirements from both students and tutors and can be presented as an appropriate learning environment. To be able to use a LMS the ESP students should be provided with corresponding computer equipment. A Learning Centre, as a complementary learning environment, can be of much help in this case. Other applications of a Learning Centre can be used as a meeting place for learning student groups or as a silent virtual classroom that is intended to focus on studies contrary to studying at home and in this way to conquer both students and tutors perspective regarding social 
interaction in distance education. Future studies can be focused on students ESP learning processes and features a LMS has to offer for successful education on distance. Another future issue would be to compare students who are involved in distance education with those who are not familiar with such kind of studies. The issue of sufficient interest is to analyse the gender differences, age differences of the learners and if there are any, it would also be a kind of important research in the field of ESP distance education [10].

ESP discourse mastering is aimed at developing students' English for specific purposes competences (i.e. linguistic, sociolinguistic and pragmatic ones) which will enable them to effectively communicate in their future professional environment. Adequate understanding of authentic materials from Internet sources, specialist journals, instructions, specifications for equipment operation and maintenance is the result of the previous thorough ESP discourse studies and proper skills developed based on social interaction. Maximization of the latter for increasing its efficiency and effectiveness is quite obvious since other job-related activities also require high level ESP discourse training and the corresponding social interaction skills and feedback. It refers to:

- participation in common social, academic and professional settings (meetings, seminars, discussions, talks, debates, etc.),

- supporting personal professional ideas and point of view with clear argumentation,

- delivering presentations,

- conducting lectures,

- making telephone calls,

- organising video-conferences, webinars,

- being members of International cooperation and exchange programmes,

- business correspondence in standard format (e-males, letters, reports, grant proposals, analytical reviews, etc.) for a variety of purposes related to the professional sphere.

Conclusions. Maximizing social interaction in the virtual classroom directly depends on students' motivation based on their understanding of the ESP discourse practical application as well as on building teacher-student/student-student/student-teacher rapport in terms of mutual respect, trust and group cohesion. Knowledge acquired in the process of ESP discourse training combined with reduced anxiety due to the positive supportive atmosphere leads to beneficial outcomes.

\section{References:}

1. Vuopala, Essi, Hyvönen, Pirkko, Järvelä Sanna. Interaction forms in successful collaborative learning in virtual learning environments. Active Learning in Higher Education. 2016. Volume 17, Issue 1. P. 25-38. DOI: https://doi.org/10.1177/1469787415616730

2. Hill, J.R., Song, L., West, R.E. Social Learning Theory and Web-Based Learning Environments: A Review of Research and Discussion of Implications. American Journal of Distance Education. 2009. Volume 23, Issue 2. P. 88-103. DOI: https:// doi.org/10.1080/08923640902857713

3. Ingirige, Bingunath, Goulding, Jack Steven. Maximizing social interaction within distance learning ESP discourse. 2015. P. 75-99. Retrieved January 25, 2021 from http://clok.uclan.ac.uk/1623/1/ BingunathIngirige4(1)_1623.pdf

4. Kreijns, K., Kirschner, P.A., Jochems W. Identifying the pitfalls for social interaction in computer-supported collaborative learning environments: a review of the research. Computers in Human Behavior. May 2003. Volume 19, Issue 3. P. 335-353. DOI: https:// doi.org/10.1016/S0747-5632(02)00057-2
5. Laffey, J., Lin, G.Y. \& Lin, Y. Assessing Social Ability in Online Learning Environments. Journal of Interactive Learning Research. 2006. 17(2). P. 163-177. Retrieved January 23, 2021 from https:// www.learntechlib.org/primary/p/5981/

6. Howarth Patrick. Increasing student interaction. URL: https://www. teachingenglish.org.uk/article/increasing-student-interaction

7. Evans, S. Designing email tasks for the business English classroom: Implications from a study of key industries. English for Specific Purposes Journal. 2012. 31(3). P. 202-212.

8. Ilie Cornelia, Nickerson Catherine, Planken Brigitte. Teaching Business Discourse (Research and Practice in Applied Linguistics). Palgrave Macmillan, 2019. 196 p.

9. Soong, M.H.B., Chan, H.C., Chua, B.C., Lon, K.F.: Critical success factors for on-line course resources. Computers and Education. 2001. Vol. 36. P. 101-120.

10. Mörndal Marie, Révay Péter. Distance education - social interaction in a learning environment. 2005. URL: http://www.diva-portal.org/ smash/get/diva2:113661/FULLTEXT01.pdf

Байбакова І.М., Гасько О.Л. Максимізація соціальної взасмодії в умовах дистанційного вивчення дискурсу на занятті англійської мови фахового спрямування

Анотація. Успішний досвід дистанційного навчання залежить від соціальної взаємодії, максимізація якої набуває першочергового значення як важливий чинник віртуальної освітньої складової частини. Практичне застосування соціальної взаємодії розглядається в контексті вивчення дискурсу англійської мови фахового спрямування в умовах дистанційного навчання.

Опанування фахового дискурсу спрямоване на розвиток лінгвістичних і пов'язаних із ними соціолінгвістичних і прагматичних компетентностей студентів, що сприятимуть їх майбутньому ефективному спілкуванню у професійному середовищі. Це передбачає засвоєння термінологічних одиниць, граматичних конструкцій, опрацювання професійно орієнтованої інформації. Належне розуміння автентичних матеріалів Інтернет-джерел, журналів, інструкцій, специфікацій є результатом попереднього детального вивчення фахового дискурсу та здобуття навичок, основу яких становить соціальна взаємодія. Максимізація останньої для підвищення іiі ефективності та результативності є цілком очевидною, оскільки інші види професійної діяльності спеціаліста також вимагають високого рівня підготовки щодо фахового дискурсу та належних навичок соціальної взаємодії та зворотного зв'язку. Це стосується участі у спільних соціальних, академічних і професійних заходах (зустрічі, семінари, дискусії, бесіди, дебати тощо), висловлювань особистих професійних ідей/точки зору з чіткою аргументацією, проведення лекцій та презентацій, здійснення телефонних дзвінків, організації відеоконференцій, вебінарів, програм міжнародного співробітництва та обміну, ведення ділової кореспонденції і наукових публікацій у стандартному форматі (листи, звіти, пропозиції грантів, аналітичні огляди, статті тощо).

Максимізація ефективності соціальної взаємодії у віртуальному класі безпосередньо залежить від мотивації студентів на основі їх усвідомлення практичного застосування фахового дискурсу, вивчення якого в поєднанні з позитивною атмосферою взаєморозуміння, поваги, довіри та згуртованості групи призводять до успішних результатів.

Ключові слова: соціальна взаємодія, дистанційне навчання, дискурс англійської мови фахового спрямування, діяльність, пов'язана з роботою, взаєморозуміння. 